Int. J. Electrochem. Sci., 16 (2021) Article ID: 210352

International Journal of

ELECTROCHEMICAL

SCIENCE

$\underline{\text { www.electrochemsci.org }}$

\title{
Cerium Doped Trimethoxy Silane-Aluminium Isopropoxide Coatings for Enhanced Corrosion Protection of 1061 Aluminum Alloy in Aqueous Sodium Chloride Solution
}

\author{
Wei Liu, Chengqiang An*, Jianjun Hao, Wenruo Li
}

School of Environmental and Chemical Engineering, Shenyang Ligong University, Shengyang, 110159, P R China

*E-mail: $1031757850 @$ qq.com

doi: $10.20964 / 2021.03 .18$

Received: 2 October 2020 / Accepted: 18 December 2020 / Published: 31 January 2021

\begin{abstract}
Aluminum alloy is the most widely used light metal material in recent years, and the corrosion resistance of aluminum alloy is currently a research hotspot in the field of materials. In this work, the purpose of using $\mathrm{Ce}\left(\mathrm{NO}_{3}\right)_{3}$ doped trimethoxy silane-aluminium isopropoxide (GPTMS-AIP) coating is to improve the corrosion resistance of aluminum alloy. SEM, EDS and Fourier transform infrared spectroscopy(FT-IR) were used to analyze the microscopic morphology and composition of the coating, and the potentiodynamic polarization measurements and electrochemical impedance method were used to investigate the influence of the content on the corrosion resistance of the coating and the corrosion behavior of the coating. The results showed that when the addition amount of $\mathrm{Ce}\left(\mathrm{NO}_{3}\right)_{3}$ was $0.5 \mathrm{~g} / \mathrm{L}$, the coating was homogeneous and flat with fewer defects. The corrosion behavior analysis proves that $\mathrm{Ce}^{3+}$ in the coating is released to generate $\mathrm{Ce}(\mathrm{OH})_{3}$ and $\mathrm{CeO}_{2}$, which can repair the coating and make coating have a certain self-repairing effect.
\end{abstract}

Keywords: corrosion resistance, self-repairing, composite coating, rare-earth salts

\section{$\underline{\text { FULL TEXT }}$}

(C) 2021 The Authors. Published by ESG (www.electrochemsci.org). This article is an open access article distributed under the terms and conditions of the Creative Commons Attribution license (http://creativecommons.org/licenses/by/4.0/). 